\title{
Comparison of isotopic turnover dynamics in two different muscles of a coral reef fish during the settlement phase
}

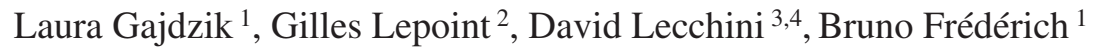 \\ ${ }^{1}$ Laboratoire de Morphologie Fonctionnelle et Evolutive, AFFISH Research Centre, Université de Liège, B-4000 Liège, \\ Belgium. E-mail: bruno.frederich@ulg.ac.be \\ ${ }^{2}$ MARE, Laboratoire d'Océanologie, Université de Liège, B-4000 Liège, Belgium. \\ ${ }^{3}$ USR 3278 CNRS-EPHE-UPVD, CRIOBE, 98729 Moorea, French Polynesia. \\ ${ }^{4}$ Laboratoire d'Excellence "CORAIL”, 98729 Moorea, French Polynesia.
}

\begin{abstract}
Summary: The temporal variation in carbon and nitrogen isotopic compositions (noted as $\delta^{13} \mathrm{C}$ and $\delta^{15} \mathrm{~N}$ ) was investigated in the convict surgeonfish (Acanthurus triostegus) at Moorea (French Polynesia). Over a period of 24 days, juveniles were reared in aquaria and subjected to two different feeding treatments: granules or algae. The dynamics of $\delta^{13} \mathrm{C}$ and $\delta^{15} \mathrm{~N}$ in two muscles (the adductor mandibulae complex and the epaxial musculature) having different functions were compared. At the end of experiments, a steady-state isotopic system in each muscle tissue was not reached. Especially for the algal treatment, we found different patterns of variation in isotopic compositions over time between the two muscles. The turnovers of $\delta^{13} \mathrm{C}$ showed opposite trends for each muscle but differences are mitigated by starvation and by the metamorphosis. Our study highlighted that the metabolism of coral reef fish may be subjected to catabolism or anabolism of non-protein precursors at settlement, inducing variation in isotopic compositions that are not linked to diet change.
\end{abstract}

Keywords: Acanthuridae; stable isotopes; development; ontogeny; metamorphosis; starvation; surgeonfish.

Comparación de la dinámica de variación isotópica en dos músculos de un pez de arrecife de coral durante la fase de asentamiento

Resumen: La variación temporal en la composiciones isotópicas del carbono y nitrógeno $\left(\delta^{13} \mathrm{C}\right.$ y $\left.\delta^{15} \mathrm{~N}\right)$ fue investigada en el pez cirujano Acanthurus triostegus en Moorea (Polinesia Francesa). Durante un período de 24 días, peces juveniles se mantuvieron en acuarios y se sometieron a dos tratamientos de alimentación: gránulos o algas. Se compararon las dinámicas de cambio $\delta^{13} \mathrm{C}$ y $\delta^{15} \mathrm{~N}$ en dos músculos con diferentes funciones (complejo aductor mandibular y musculatura epiaxial). Al final de los experimentos, no se alcanzó un sistema isotópico de estado estacionario en ningún tejido. Especialmente para el tratamiento de algas, encontramos distintos patrones de variación en composiciones isotópicas en el tiempo entre los dos músculos. Las variaciones en $\delta^{13} \mathrm{C}$ mostraron tendencias opuestas para cada músculo, pero las diferencias fueron mitigadas por la inanición y la metamorfosis. Nuestro estudio destaca que el metabolismo de los peces de arrecife puede ser sometido a catabolismo o anabolismo por los precursores no proteicos durante el asentamiento, induciendo variación en las composiciones isotópicas que no están vinculados al cambio de dieta.

Palabras clave: Acanthuridae; isótopos estables; desarrollo; ontogenia; metamorfosis; inanición; surgeonfish.

Citation/Como citar este artículo: Gajdzik L., Lepoint G., Lecchini D., Frédérich B. 2015. Comparison of isotopic turnover dynamics in two different muscles of a coral reef fish during the settlement phase. Sci. Mar. 79(3): 325-333. doi: http:// dx.doi.org/10.3989/scimar.04225.31A

Editor: M.P. Olivar.

Received: February 10, 2015. Accepted: June 16, 2015. Published: September 16, 2015.

Copyright: (c) 2015 CSIC. This is an open-access article distributed under the Creative Commons Attribution-Non Commercial Lisence (by-nc) Spain 3.0.

\section{INTRODUCTION}

The life cycle of the majority of reef fishes is a complex process that comprises two main distinct phases, a pelagic larval stage corresponding to long-distance migrations of larvae and a demersal stage that includes juveniles as well as adults (Leis 2002, Lecchini and Galzin 2003). The larval phase ends with the coral reef settlement (Leis 2002). The shift from a pelagic to a benthic environment represents a period of transition 
during which fishes undergo morphological, physiological and behavioural changes (e.g. McCormick and Makey 1997, Lecchini 2005). This major event in the life history of reef fishes is generally called metamorphosis (McCormick and Makey 1997) and may correspond to rapid variations in internal stable isotope compositions (Herzka and Holt 2000). Thus, comparing carbon and nitrogen isotopic compositions during that phase might provide information about physiology and tissue turnover.

During the last few decades, stable isotopes have emerged as common tools for investigating food webs, trophodynamics and trophic ecology by defining trophic levels and identifying the diets of consumers (e.g. Lepoint et al. 2004, Carassou et al. 2008). The isotopic turnover can be defined as the rate at which elemental isotopes in the diet are incorporated into the consumer (Tieszen et al. 1983). Various studies have compared the rates of isotopic turnover between different types of tissues in fishes. For example, Olsen et al. (2015) found that the isotopic turnovers in plasma, muscle and heart reached a steady state faster than in the liver of the Atlantic cod Gadus morhua. The turnover of isotopes may also vary greatly among fish species. For example, the $\delta^{13} \mathrm{C}$ and $\delta^{15} \mathrm{~N}$ values of red drum (Sciaenops ocellatus) larvae indicated that carbon and nitrogen both have rapid turnovers that matched the very high growth rate of young fish because the isotopic compositions shift in 1-2 days and stabilize within 10 days (Herzka and Holt 2000). A study conducted on the winter flounder (Pseudopleuronectes americanus) indicated that a stable system could occur within a period of 16 days in recently metamorphosed fish (Bosley et al. 2002). On the other hand, a one-year study revealed that the isotopic equilibrium with food sources could take several months in 2.5-year-old Coregonus nasus (Hesslein et al. 1993). These studies have provided reliable data about isotopic turnovers and allow comparisons among species. However few studies have focused on changes in isotope compositions during the growth of coral reef fishes correlated with diet shifts (but see Frédérich et al. 2010, 2012) and information about the dynamics of isotopic turnover during the settlement phase of tropical reef fishes is unavailable.

In studies devoted to the trophic ecology of tropical reef fishes (e.g. Carassou et al. 2008, Frédérich et al. 2009, Gajdzik et al. 2014), the epaxial musculature is usually sampled for the isotopic analyses. To our best knowledge, no study has compared the ontogenetic dynamics of isotopic turnover from different muscles in a coral reef fish during the transition phase from the pelagic to the benthic environment. Here, we compared the variation of isotopic composition in two muscles having different functions: the adductor mandibulae complex, which generates jaw-closing movements during feeding, and the epaxial musculature involved in swimming activities (Vandewalle 1978, Lauder 1980). In grazing reef fishes (e.g. acanthurids and scarids), there is a drastic ontogenetic shift correlated with a change in prey consumed between settling larvae and adults that corresponds to a diet change from zooplanktivory to benthivory (Frédérich et al. 2012).
This probably impacts the metabolism of each muscle in a different manner. For example, the activity of the adductor mandibulae complex should be more intense in juveniles and adults as they graze on algae in comparison with larvae feeding on zooplanktonic preys (Sampey et al. 2007). Therefore, the growth of both muscles could reflect different isotopic dynamics related to their development and functional demands.

The present study explored experimentally the dynamics of carbon and nitrogen stable isotopes during the first 24 days of post-settlement in an algivorous coral reef fish, Acanthurus triostegus. We specifically targeted two muscles having different functions: the adductor of mandibulae involved in feeding activity and the epaxial musculature used for locomotion. Our objectives were to compare the dynamics of isotopic turnover in each muscle type when fish were fed with different diets (artificial granules vs algae). We expected variation in the patterns of isotopic turnover between muscles and between diet treatments. We hypothesized that the turnover of both isotopes in the adductor mandibulae would be more rapid than in epaxial musculature, especially for the algal treatment. Indeed, the juvenile oral morphology should become shaped for grazing and algal treatment would stimulate morphological adaptations for biting (Frédérich et al. 2012). According to the metamorphosis hypothesis, when reef fishes undergo morphological and physiological changes in a short period of time, we expected carbon and nitrogen composition in each tissue to approximate the equilibrium with the isotopic composition of their diets at the end of the experiments (i.e. 24 days).

\section{MATERIALS AND METHODS}

\section{Target species}

The convict surgeonfish, Acanthurus triostegus (Linnaeus, 1758), was chosen as a model to carry out such a study given its widespread distribution in the Indo-Pacific region (Randall 1961). At Moorea (French Polynesia), the larval stage is about 44 to 60 days, after which larvae colonize the reef at night and settle directly on shallow sandy areas with coral slabs (McCormick 1999, Lecchini and Galzin 2005). When sexual maturity is reached (standard length, SL=95 $\mathrm{mm}$ ), adults move towards the barrier reef community, where they usually form large feeding schools (Randall 1961). Larvae feed on zooplankton while juveniles and adults graze on algae (Frédérich et al. 2012).

\section{Sampling and experiment}

Sample collection was carried out in SeptemberOctober 2009 in the lagoon of Moorea $\left(17^{\circ} 30^{\prime} \mathrm{S}\right.$, 149 $50^{\circ}$ 'W; French Polynesia; Fig. 1). Settling larvae of Acanthurus triostegus ( $\mathrm{n}=81$ ), also called "naïve" larvae, were obtained from nets fixed to the reef crest at dawn (Lecchini et al. 2006). The first surgeonfish larvae, which were captured all at once $(n=17)$ and formed one cohort, were sacrificed and represent the $t_{0}$ in the following framework. The other larvae $(n=64)$, caught 


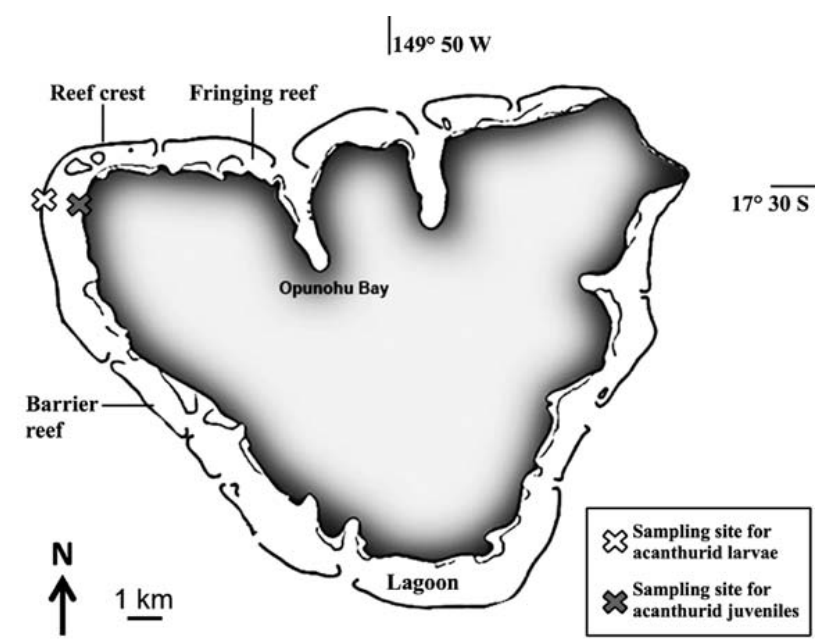

Fig. 1. - Map of Moorea (French Polynesia). The sampling sites are the same as in Frédérich et al. (2012).

during another retrieval of nets, form a second cohort which was divided into two equal parts. Each half was allocated to a feeding treatment $(n=32$ for treatment 1 and $n=32$ for treatment 2). For a comparison between treatment 2 and juveniles collected in the field, we used the isotopic data of the epaxial musculature from 91 individuals (SL, 22.45-55.25 mm) captured at the same location and same date, and published in Frédérich et al. (2012). Juveniles were caught with a seine net on the beach zone (Fig. 1). Throughout the paper, we use the term "larvae" for individuals collected with crest nets and the term "juveniles" for fish maintained in aquaria. Treatment 1 consisted of providing commercially available granules, especially adapted for coral reef fish (SERA marin granules). These granules are composed of $52 \%$ proteins, $8.1 \%$ fat content, $3.5 \%$ crude fibres, $6.5 \%$ inorganic matter and $5.1 \%$ moisture. In treatment 2 , the food sources were algae growing on stones/rubbles and found near beach shores. They were a mix of filamentous algae, red algae (Polysiphonia spp.) and green algae (Enteromorpha spp.) and represent the putative natural food of this species during the juvenile phase (Ogden and Lobel 1978, Frédérich et al. 2012).

\section{Sampling treatment}

The cohort of 64 larvae was equally separated into two aquaria of $200 \mathrm{~L}(100 \times 50 \times 40)$ filled with running sea water at a constant temperature of $26^{\circ} \mathrm{C}$. Daylight simulation provided $12 \mathrm{~h}$ of light/darkness. In treatment 1 , a total of 32 larvae were fed with granules three times per day. In treatment 2 , the bottom of each aquarium was fully filled with stones or coral rubbles covered by turf algae, which were replaced daily. The experiments lasted 24 days, during which three to five individuals were randomly sampled every three days and then killed with an overdose of tricaine methanesulfonate (MS-222) according to ethical recommendations. All fish were measured and weighed. The SL was taken to the nearest millimeter with a Vernier caliper. Muscle tissue (0.5-2 $\mathrm{cm}^{3}$ ) from the epaxial section of the fish body and of the adductor mandibulae complex were sampled.

\section{Processing for stable isotopes analysis}

Samples of both types of muscle tissues and food sources (i.e. granules and algae) were dehydrated for $48 \mathrm{~h}$ at $60^{\circ} \mathrm{C}$ before being ground into a homogenous powder. After grinding, samples containing carbonates (brushed algae) were placed for $24 \mathrm{~h}$ under a glass bell with fuming $\mathrm{HCl}(37 \%)$ (Merck $\mathrm{KGaA}^{\odot}$, for analysis quality) in order to eliminate calcareous material.

Samples were analysed on a V.G. Optima (Micromass) IR-MS coupled to an N-C-S elemental analyser (Carbo Erba). Routine measurements were precise to within $0.3 \%$ for both $\delta^{13} \mathrm{C}$ and $\delta^{15} \mathrm{~N}$ values. Carbon and nitrogen isotope ratios were reported as per mil $(\% \circ)$ and expressed in the conventional delta notation $\left(\delta^{13} \mathrm{C}, \delta^{15} \mathrm{~N}\right)$ relative to the vPDB (Vienna Peedee Belemnite) standard and to atmospheric nitrogen standard, respectively. Certified materials were IAEA-N1 $\left(\delta^{15} \mathrm{~N}=0.4 \pm 0.2 \%\right.$ ) and IAEA CH-6 (sucrose) $\left(\delta^{13} \mathrm{C}=-10.4 \pm 0.2 \%\right)$ :

$$
\delta \mathrm{X}=[(\text { Rsample } / \text { Rstandard })-1] \times 1000
$$

where $\mathrm{X}$ is either ${ }^{13} \mathrm{C}$ or ${ }^{15} \mathrm{~N}$ and $\mathrm{R}$ is the ratio of the heavy to the light isotope.

\section{Statistical analysis}

At settlement $\left(\mathrm{t}_{0}\right)$, significant differences in composition of carbon and nitrogen between the two types of muscles were checked using a Student t-test when variances were normally distributed and homogeneous (Shapiro-Wilk test and Levene test, respectively) and a Welch test when unequal variances were found even after transformation. For each food treatment lasting from $t_{3}$ to $t_{24}$, the relationship between $\delta^{13} \mathrm{C}$, $\delta^{15} \mathrm{~N}$ or elemental ratio of carbon to nitrogen $(\mathrm{C} / \mathrm{N})$ and time was investigated using two types of model: (1) an exponential model plateau followed by one phase decay and (2) a linear regression model. The equation of the exponential model plateau followed by one phase decay is:

$$
\delta_{\mathrm{t}}=\delta_{\mathrm{f}}+\left(\delta_{\mathrm{i}}-\delta_{\mathrm{f}}\right) \mathrm{e}^{(-\mathrm{vt})}
$$

where $\delta_{t}$ is the stable isotopic composition of either adductor mandibulae or the epaxial musculature at the time when fish were collected from the aquaria, $\delta_{i}$ is the initial value before the diet switch, $\delta_{\mathrm{f}}$ is the final isotopic composition equilibrated to the new diet, $\mathrm{v}$ is a measure of the turnover rate and $t$ is the time that the fish were in the experiment (day) (Tieszen et al. 1983). This model allows for the calculation of the "Trophic Enrichment Factor" (TEF) which is the arithmetic difference in the nitrogen isotope ratio of consumer and $\operatorname{diet}\left(\delta^{15} \mathrm{~N}=\delta^{15} \mathrm{~N}_{\text {consumer }}-\delta^{15} \mathrm{~N}_{\text {diet }}\right)$.

The equation for the linear regression model is:

$$
\mathrm{Y}=\beta+\alpha \mathrm{X}
$$

where $\beta$ is the $y$-intercept and $\alpha$ the slope of the linear regression. 
$328 \cdot$ L. Gajdzik et al.

Table 1. - Composition of $\delta^{13} \mathrm{C}$ and $\delta^{15} \mathrm{~N}$ in 16 larvae of Acanthurus triostegus at reef settlement $\left(\mathrm{t}_{0}\right)$ from Moorea in 2009. Mean value and standard deviation (sd) are also presented.

\begin{tabular}{|c|c|c|c|c|c|c|c|}
\hline \multirow[b]{2}{*}{ Individuals } & \multirow[b]{2}{*}{$\begin{array}{l}\text { Standard length } \\
(\mathrm{mm})\end{array}$} & \multicolumn{3}{|c|}{ Adductor mandibulae } & \multicolumn{3}{|c|}{ Epaxial musculature } \\
\hline & & $\delta^{13} \mathrm{C}(\% \circ)$ & $\delta^{15} \mathrm{~N}(\% o)$ & $\mathrm{C} / \mathrm{N}$ & $\delta^{13} \mathrm{C}(\% \circ)$ & $\delta^{15} \mathrm{~N}(\% \circ)$ & $\mathrm{C} / \mathrm{N}$ \\
\hline 1 & 24 & -20.26 & 15.78 & 3.95 & -17.75 & 18.96 & l \\
\hline 2 & 25.1 & -19.55 & / & 3.66 & -18.03 & 18.15 & 3.22 \\
\hline 3 & 23.8 & -20.02 & I & 3.87 & -17.83 & 18.42 & I \\
\hline 4 & 22.8 & -20.45 & 16.7 & 4.1 & -17.84 & 18.63 & 3.22 \\
\hline 5 & 23.7 & -20.33 & I & 4.05 & I & I & I \\
\hline 6 & 24 & -19.85 & 18.62 & 3.89 & -18.14 & 18.78 & I \\
\hline 7 & 24.1 & -19.59 & 18.3 & 3.87 & -17.82 & 18.86 & 3.23 \\
\hline 8 & 23.4 & -19.73 & I & 4 & -17.70 & 17.46 & 3.22 \\
\hline 9 & 24.5 & I & I & l & -17.91 & 18.65 & I \\
\hline 10 & 25.3 & -19.79 & 16.74 & 4.16 & -17.81 & 17.14 & I \\
\hline 11 & 25 & -20.73 & 15.29 & 4.19 & -18.03 & 17.66 & I \\
\hline 12 & 24.6 & -19.9 & / & 3.88 & -17.74 & 17.19 & 3.28 \\
\hline 13 & 24.8 & -19.95 & I & 4.21 & -17.74 & 18.63 & 3.23 \\
\hline 14 & 24 & -19.76 & 18.14 & 3.68 & -17.84 & 17.93 & I \\
\hline 15 & 24.3 & -19.92 & 17.35 & 4.05 & -17.89 & 18.83 & 3.2 \\
\hline 16 & 24.8 & -19.56 & 16.97 & 3.89 & -17.23 & 18.39 & I \\
\hline Mean \pm sd & & $-19.96 \pm 0.34$ & $17.01 \pm 1.13$ & $3.72 \pm 1.00$ & $-17.82 \pm 0.20$ & $18,24 \pm 0.62$ & $3.23 \pm 0.20$ \\
\hline
\end{tabular}

In order to perform the second model, a coefficient of correlation (r) was first calculated with Pearson's product-moment method for parametric data and Spearman's rank correlation coefficient was used for non-parametric data. If the results were significant $(\mathrm{p}<0.05)$, a linear regression model was performed and the coefficient of determination was calculated $\left(\mathrm{R}^{2}\right)$. Normality of residuals of each model was tested using a Shapiro-Wilk test. If linear models were validated, analyses of covariance tests (ANCOVA) were performed to compare the dynamics of isotopic compositions between the two muscles. All statistical analyses were done with GraphPad Prism, version 5.0 (Motulsky 2007).

\section{RESULTS}

\section{Isotopic compositions in larvae $\left(t_{0}\right)$ and food sources}

At settlement $\left(\mathrm{t}_{0}\right), \delta^{13} \mathrm{C}$ values for the adductor mandibulae ranged from $-20.73 \%$ to $-19.55 \%$ o, $\delta^{15} \mathrm{~N}$ values from $15.29 \%$ to $18.62 \%$ and carbon $(\mathrm{C})$ to nitrogen
Table 2. - Carbon and nitrogen isotope compositions (mean \pm sd) of food sources: algae growing on coral rubbles collected on the fringing reefs (Moorea) and granulated food. Standard deviations (sd) are only presented for algal food.

\begin{tabular}{lcc}
\hline Food sources & $\delta^{13} \mathrm{C}(\% \circ)$ & $\delta^{15} \mathrm{~N}(\% \circ)$ \\
\hline Granulated food & -20.60 & 8.20 \\
Algae & $-15.54 \pm 2.46$ & $13.53 \pm 0.83$ \\
\hline
\end{tabular}

$(\mathrm{N})$ ratios were about 3.66 to 4.21 (Table 1). Compositions for epaxial musculature varied from $-18.14 \%$ o to $-17.23 \%$ o for carbon and from $17.14 \%$ o to $18.96 \%$ ofor nitrogen, and the $\mathrm{C} / \mathrm{N}$ ratio ranged from 3.22 to 3.28 . Isotopic compositions in the adductor mandibulae differed significantly from values in the epaxial musculature (Welch test, $\delta^{13} \mathrm{C}, \mathrm{dF}=23, \mathrm{p}<0.05$; Student t-test, $\left.\delta^{15} \mathrm{~N}, \mathrm{dF}=22 ; \mathrm{p}<0.05 ; \mathrm{C} / \mathrm{N}, \mathrm{dF}=15, \mathrm{p}<0.05\right)$. For the food sources, granules showed more negative values of $\delta^{13} \mathrm{C}$ and lower values of $\delta^{15} \mathrm{~N}$ than algae (Table 2).

\section{Effects of food treatments on fish growth}

Acanthurus triostegus individuals fed with granules increased significantly in weight and size over time
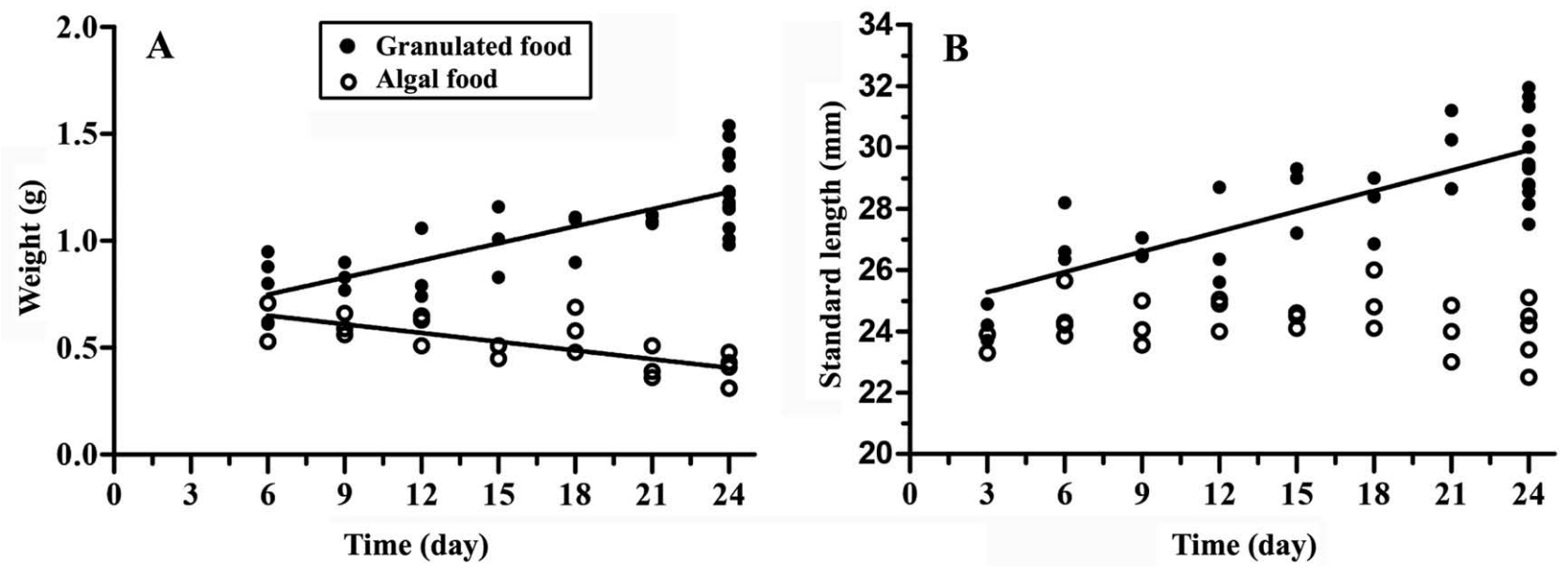

Fig. 2. - Variation of weight (A) and size (B) of Acanthurus triostegus over time during the experiments. Plotting weight vs time (A), for treatment $1 \mathrm{Y}=0.57+0.266 \mathrm{X}$ and for treatment $2 \mathrm{Y}=0.73-0.013 \mathrm{X}$. Plotting standard length vs time $(\mathrm{B})$, for treatment $1 \mathrm{Y}=24.61+0.220 \mathrm{X}$. Linear regressions are represented by straight filled lines. 

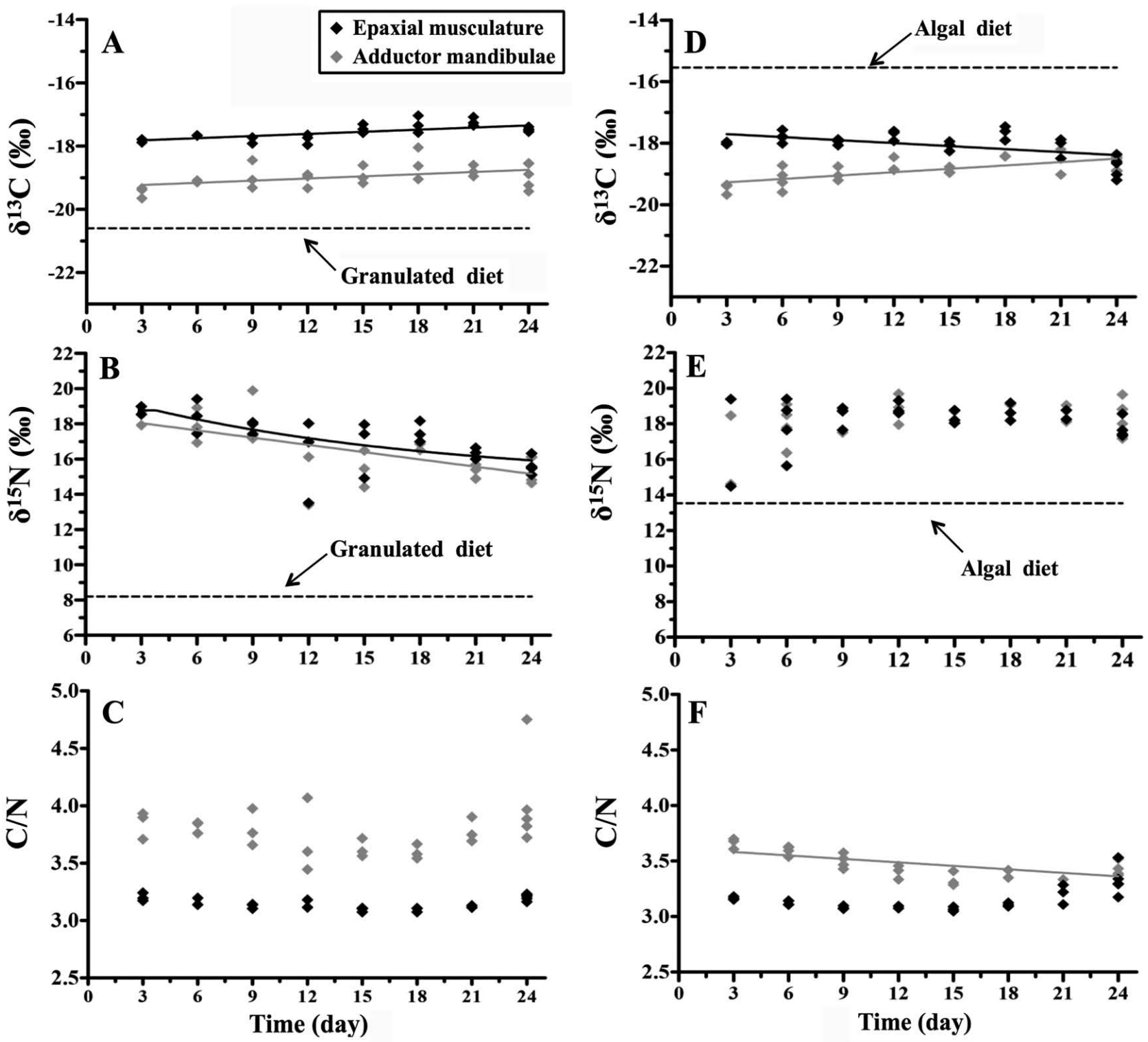

Fig. 3. - Relationship between time (day) and isotopic values $\left(\delta^{13} \mathrm{C}, \delta^{15} \mathrm{~N}\right.$ and $\left.\mathrm{C} / \mathrm{N}\right)$ in Acanthurus triostegus during treatment 1 (A, B, C) and treatment $2(\mathrm{D}, \mathrm{E}, \mathrm{F})$. Linear regressions are represented by straight filled lines.

(linear regressions $\mathrm{R}^{2}=0.64, \mathrm{p}<0.05 ; \mathrm{R}^{2}=0.53, \mathrm{p}<0.05$, respectively; Fig. 2). Conversely, there was a significant negative correlation between weight and time for fish grazing on algae (linear regression $\mathrm{R}^{2}=0.53$, $\mathrm{p}<0.05$; Fig. $2 \mathrm{~A})$. These fish did not increase in size during the experiment $\left(\mathrm{t}_{6}, 23.85 \mathrm{~mm}\right.$ and $0.53 \mathrm{~g} ; \mathrm{t}_{24}$, $22.50 \mathrm{~mm}$ and $0.31 \mathrm{~g}$; Fig. 2B).

\section{Treatment 1: patterns of isotopic variation in} juveniles fed with granulated food

Results of linear regression models of both experiments are presented in Table 3. The turnover of $\delta^{13} \mathrm{C}$ in the adductor mandibulae and in the epaxial musculature showed the same increasing linear dynamics (ANCOVA, test for common slopes, $\mathrm{F}_{1,47}=0.0016$, $p>0.05$; Fig. $3 A$ ). On the other hand, the $\delta^{15} \mathrm{~N}$ values were decreasing for both types of muscles but their dynamics were different. Nitrogen values in the adductor mandibulae complex decreased linearly over time (mean value of $15.56 \%$ at the end of the experiment). The isotopic composition in epaxial musculature of each individual fitted an exponential model, whose values reached a plateau at $14.76 \%$ o (Table 3, Fig. 3B). This exponential model allowed the calculation of the TEF, which is $6.56 \%$. The $\mathrm{C} / \mathrm{N}$ ratio remained quite stable over time for each type of muscle. For both muscles, no significant correlation was found between the $\mathrm{C} / \mathrm{N}$ ratio and time (Table 3 , Fig. 3C).

Treatment 2: patterns of isotopic variation in juveniles fed with algal food

When larvae were fed with turf algae, $\delta^{13} \mathrm{C}$ values of both muscles showed opposite dynamics during 
Table 3. - Results of models: type of model, coefficient of determination $\left(\mathrm{R}^{2}\right)$ and p-value for $\delta^{13} \mathrm{C}, \delta^{15} \mathrm{~N}$ and carbon $(\mathrm{C})$ and nitrogen $(\mathrm{N})$ ratio of Acanthurus triostegus caught at Moorea in 2009. Only means of intercept and slope are presented. AM and EM refer to the adductor mandibulae complex and epaxial musculature, respectively; ns, "non-significant"; *, p-value $<0.05$.

\begin{tabular}{|c|c|c|c|c|c|c|}
\hline Treatments & Y vs X & Muscle & $\begin{array}{l}\text { Exponential model: } \\
\text { plateau followed by one phase decay }\end{array}$ & Linear regression model & $\mathrm{R}^{2}$ & $\mathrm{P}$ \\
\hline \multirow{6}{*}{$\begin{array}{l}\text { Exp. 1: } \\
\text { Granules }\end{array}$} & \multirow{2}{*}{$\delta^{13} \mathrm{C}$ vs time } & AM & ns & $Y=-19.30+0.022 X$ & 0.21 & * \\
\hline & & EM & ns & $Y=-17.89+0.022 X$ & 0.44 & $*$ \\
\hline & \multirow{2}{*}{$\delta^{15} \mathrm{~N}$ vs time } & AM & ns & $Y=18.45-0.137 X$ & 0.42 & $*$ \\
\hline & & EM & $\mathrm{Y}=14.76+3.998 \mathrm{e}^{-(0.061 \times 3.789)}$ & ns & 0.43 & $*$ \\
\hline & \multirow{2}{*}{$\mathrm{C} / \mathrm{N}$ vs time } & AM & ns & ns & ns & ns \\
\hline & & EM & ns & ns & ns & ns \\
\hline \multirow{6}{*}{$\begin{array}{l}\text { Exp. 2: } \\
\text { Algae }\end{array}$} & \multirow[b]{2}{*}{$\delta 13 \mathrm{C}$ vs time } & AM & ns & $Y=-19.38+0.036 X$ & 0.49 & $*$ \\
\hline & & EM & ns & $Y=-17.61-0.032 X$ & 0.32 & $*$ \\
\hline & \multirow{2}{*}{$\begin{array}{l}\delta 15 \mathrm{~N} \text { vs } \\
\text { time }\end{array}$} & AM & ns & ns & ns & ns \\
\hline & & EM & ns & ns & ns & $\mathrm{ns}$ \\
\hline & \multirow{2}{*}{$\mathrm{C} / \mathrm{N}$ vs time } & AM & ns & $Y=3.61-0.010 X$ & 0.41 & $*$ \\
\hline & & EM & ns & ns & ns & ns \\
\hline
\end{tabular}

the experiment (ANCOVA, test for common slopes: $\mathrm{F}_{1,48}=31.45, \mathrm{p}<0.05$; Table 3$)$. Values of $\delta^{13} \mathrm{C}$ increased linearly towards food source for the adductor mandibulae (i.e. reaching less negative values) while they decreased for the epaxial musculature (Fig. 3D) but values for each muscle tended towards $-18.64 \%$ o and $-18.77 \%$, respectively. For both types of muscles, $\delta^{15} \mathrm{~N}$ values did not change significantly over time (Table 3, Fig. 3E). The data did not fit exponential models (Table 3). The $\mathrm{C} / \mathrm{N}$ ratio of the adductor mandibulae decreased linearly over time $(r=0.41, \mathrm{p}<0.05$; Table 3, Fig. 3F). Conversely, no relationship was found between $\mathrm{C} / \mathrm{N}$ ratio in epaxial musculature and time (Table 3).

\section{Comparison with populations of juveniles from the field}

No correlation was found between $\delta^{13} \mathrm{C}$ or $\delta^{15} \mathrm{~N}$ and the SL of juvenile specimens from the field ( $\mathrm{p}>0.05)$. Therefore, no model was estimated. However, the $\mathrm{C} / \mathrm{N}$ ratio decreased linearly for both muscles (linear regression, adductor mandibulae $\mathrm{Y}=4.30-0.019 \mathrm{X}\left[\mathrm{R}^{2}=0.30\right.$; $\mathrm{p}<0.05]$ and epaxial musculature $\mathrm{Y}=3.28-0.004 \mathrm{X}$ $\left[\mathrm{R}^{2}=0.39\right.$; $\mathrm{p}<0.05$; Fig. 4]).

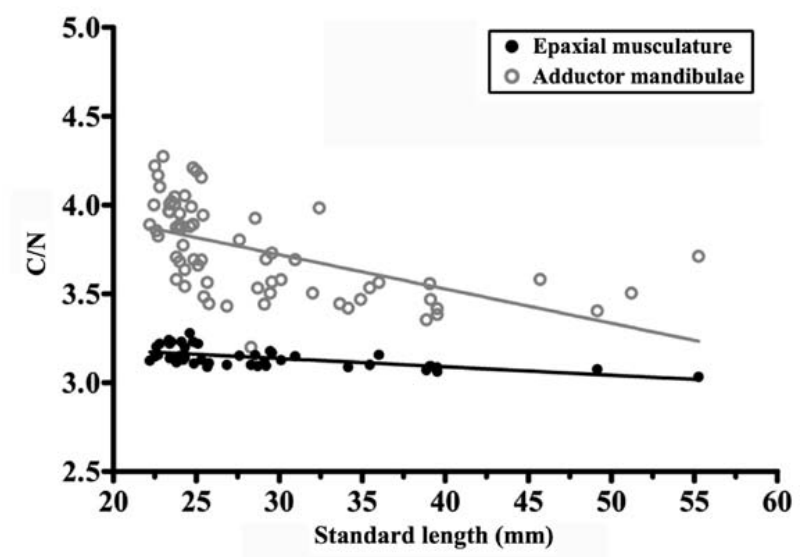

Fig. 4. - Relationship between size (standard length, SL) and carbon/ nitrogen $(\mathrm{C} / \mathrm{N})$ ratio in larvae and juveniles of Acanthurus triostegus from Moorea caught in 2009. Linear regression for the adductor mandibulae complex $\mathrm{Y}=4.30-0.0190 \mathrm{X}\left(\mathrm{R}^{2}=0.30 ; \mathrm{p}<0.001\right)$ and for the epaxial musculature $\mathrm{Y}=3.28-0.004 \mathrm{X}\left(\mathrm{R}^{2}=0.39 ; \mathrm{p}<0.05\right)$. Linear regression is represented by straight filled lines.

\section{DISCUSSION}

\section{Natural variation in stable isotope compositions in settling larvae}

At settlement $\left(\mathrm{t}_{0}\right)$, the isotopic compositions differ significantly between muscles and this tissue-specific variation can be explained by physiological factors. Indeed, white muscles are less variable in $\delta^{13} \mathrm{C}$ and $\delta^{15} \mathrm{~N}$ than red muscles (Pinnegar and Polunin 1999). The adductor mandibulae of fish have a mix of fast (i.e. white muscle) and slow fibres (i.e. red muscle) (HernandezLagunas et al. 2005), while a thin superficial layer of red fibres covers the main white fibres making epaxial musculature (Rowlerson et al. 1985). Therefore, the amount of red fibres between the adductor mandibulae and the epaxial musculature in acanthurid larvae may be different and might significantly influence their isotopic and elemental compositions. A variation of the discrimination factors between muscle tissues can also explain this difference of isotopic compositions (Caut et al. 2009).

The $\mathrm{C} / \mathrm{N}$ ratios are relatively high in $A$. triostegus larvae and juveniles (i.e. >3.2) (Table 1, Figs 3C, F and 4), suggesting the presence of carbon-rich compounds in muscle tissues (Sweeting et al. 2006). This probably comes from the lipid-rich planktonic diet of larvae, which allows them to store enough fat during the pelagic larval phase. In a natural population, this ratio decreased significantly when fish grew, meaning that lipid stores are used during the settlement phase (Fig. 4, McCormick and Molony 1992).

\section{Unreached isotopic equilibrium after 24 days post-settlement}

Many studies have revealed that the isotopic equilibrium can be reached after highly variable periods of time among fish species. Results of a feeding experiment on larvae of the Pacific blue fin tuna (Thunnus orientalis) showed that nitrogen values of fish approximated the isotopic composition of the food source after 20 days (Tanaka et al. 2014). In other experiments on larvae of the catfish Clarias gariepinus and Ictalurus punctatus, results of isotopic compositions reached the "plateau" phase between 4 to 10 weeks, respectively (Enyidi et al. 2013, Filbrun and Culver 2014). These 
studies were conducted on similar developmental stages (i.e. the larval stage) but tuna and catfishes did not undergo any drastic diet shift during ontogeny. Conversely, flatfishes observe a heavy metamorphosis and a diet shift from a pelagic food web towards a demersal habitat during growth. In the winter flounder (Pseudopleuronectes americanus) stable isotopes revealed that this diet shift occurred over a short period of 16 days (Bosley et al. 2002). In the present study, the isotopic equilibrium for A. triostegus was not reached after 24 days post-settlement although most marine ecologists agree that coral reef fishes observe a metamorphosis around this phase. Consequently, this study should probably be re-done over two or three months to define the turnover time.

\section{Effects of food treatment on isotopic dynamics in the adductor mandibulae and the epaxial musculature}

According to varied functional demands between treatments, we expected to observe differences in isotopic dynamics between muscles. Indeed, we hypothesized a higher isotopic turnover for the adductor mandibulae complex than for the epaxial musculature, especially when fish are grazing on algae. Conversely, we expected the same turnover for the epaxial musculature in both treatments because the swimming activity did not vary.

When A. triostegus were fed on granules, the adductor mandibulae complex and the epaxial musculature showed the same linear pattern of variation for the isotopic compositions of carbon (Fig. 3A and Table 3). Both tissues displayed a relatively slow turnover, as ${ }^{13} \mathrm{C}$ data followed linear models. Surprisingly, linear regressions moved in an opposite direction to the value of the food source (Fig. 3A). As granules are composed of different elements (see Materials and Methods section), we suggest that the studied surgeonfish assimilated only some components of this food. The value of the "real" food (i.e. the components really incorporated) might have a different isotopic composition from the value for the whole granule and that would explain this unexpected isotopic dynamics.

For $\delta^{15} \mathrm{~N}$, the dynamics differs between the adductor mandibulae and the epaxial musculature (Fig. 3B) although the nitrogen isotopic compositions tend to decrease over time. Accordingly with growth and weight gain (Fig. 2), these isotopic dynamics are representative of a situation in which food contains highenergy ingredients, allowing synthesis of new muscle fibres. The equilibrium for the adductor mandibulae was not reached at the end of the experiment (24 days), contrary to epaxial musculature values, which fitted an exponential model, allowing a TEF of $6.56 \%$ o to be calculated for nitrogen. This value is higher than the one found in another algivorous surgeonfish, Acanthurus sohal $(\mathrm{TEF}=4.69 \%$; Mill et al. 2007) but close to other TEFs recorded for tropical herbivorous fishes (Mill et al. 2007, Hata and Umazawa 2011). Currently, such a high TEF for herbivorous species is the subject of controversy among ecologists using stable isotopes. Vari- ous studies have found that discrimination factors depend on the species, the trophic position of the species, diet isotopic ratio and tissue, and a better quality food is apparently correlated with lower $\delta^{15} \mathrm{~N}$ enrichment (Vanderklift and Ponsard 2003, Caut et al. 2009, Wyatt et al. 2010). However, Mill et al. (2007) demonstrated that high TEF was expected for herbivores, partly as a consequence of their very high ingestion rate. The observed TEF value of $6.56 \%$ might be partially determined by the selective assimilation of granule components (see above) or by a failure to properly model the isotope dynamics with the time-limited data.

Contrary to our hypothesis, muscle isotopic composition changed faster in the epaxial musculature than in the adductor mandibulae complex. This might be due to the fact that feeding on a more pelagic type of food (i.e. granules) does not require better-developed adductor mandibulae muscle than feeding on benthic algae (Frédérich et al. 2008). Perhaps granules or the "absence of biting on the benthos" do not induce the expected morphological and physiological changes (e.g. the development of large adductor mandibulae and robust oral jaws) required to efficiently graze on turf algae (Frédérich et al. 2008, 2012).

When algae were provided to A. triostegus juveniles, the $\delta^{13} \mathrm{C}$ turnovers were different between the two types of muscles. Values of $\delta^{13} \mathrm{C}$ in the adductor mandibulae increased towards the mean value of isotopic composition in algae (i.e. -15.54\%o) (Table 2). For the epaxial musculature, $\delta^{13} \mathrm{C}$ values showed an opposite trend and shifted away from the food source value. This pattern suggests that epaxial musculature is probably used as a carbon source to favour the construction of a stronger jaw-closing system, increasing the efficiency to scrape algae. Moreover, the diet shift from "feeding on pelagic prey" to grazing could act as an environmental factor favouring or inducing morphological and physiological adaptations for algivory during ontogeny (Frédérich et al. 2012). The decreasing $\mathrm{C} / \mathrm{N}$ ratio in the adductor mandibulae (Fig. 3F) sustains the hypothesis of a high level of activity and lipid loss in this muscle complex compared with the unchanged $\mathrm{C} / \mathrm{N}$ ratio during treatment 1 (Fig. 3C; Schmidt et al. 2003, Logan et al. 2008).

\section{Effects of starvation and metamorphosis on the dynamics of isotopic composition}

During treatment 2, fish suffered from starvation, as suggested by their significant loss of weight (Fig. 2). Although we used the natural food source of A. triostegus (i.e. turf algae covering beach rocks or rubbles), the quantity of algae was dependent on the surface of the aquaria, inducing a limited amount of food source. In fact, starvation is a critical phase during which there is a continuous flow of molecules through different metabolic pathways, which are difficult to disentangle (Ferron and Leggett 1994). The breakdown of proteins and other molecules (i.e. catabolism) also occurs, leading to isotopic changes that are not related to diet change (Ferron and Leggett 1994). Therefore, fasting animals may differ in their stable isotope ratios from 
organisms fed ad libitum (Guelinckx et al. 2007). If diet did not contain enough carbohydrates, proteins can be catabolized in order to provide metabolic intermediates for the synthesis of other biologically important compounds (Wilson 1994). A study on the Atlantic salmon Salmo salar revealed that fasting individuals re-used their own body fat reserves by catabolism of stored lipid and protein reserves (Doucett et al. 1999). Here, the catabolism of endogenous fat stored from epaxial musculature is plausible but not so obvious in view of the constant $\mathrm{C} / \mathrm{N}$ ratio during the treatment 2 (Fig. 3F). On the other hand, the decreasing $\delta^{13} \mathrm{C}$ values in the epaxial musculature might be due to the de novo synthesis (i.e. anabolism) of non-protein precursors such as carbohydrates for the development of other tissues such as the adductor mandibulae complex.

The $\mathrm{C} / \mathrm{N}$ ratio dynamics were highly similar in "natural populations" and during algal treatment (Figs $3 \mathrm{~F}$ and 4). This reinforces the assumption that $A$. triostegus may be subjected to catabolism or anabolism of non-protein precursors, inducing variation in isotopic compositions in different muscle types. This hypothesis is not strictly diet-specific but also physiologically due to internal metamorphosis during growth (Maruyama et al. 2001, Ankjærø et al. 2012). In this study, it is rather difficult to separate the effects of starvation and metamorphosis on the isotopic turnover dynamics in each muscle. Through our experimentation, we can argue that ecologists have to be careful about the significance of isotopic compositions in settling coral reef fish. A tissue-specific trade-off between sensitivity to changes in resource use (i.e. diet) and resistance to internal changes linked to metamorphosis probably occurs (Colborne and Robinson 2013).

\section{CONCLUSION}

This study is the first one exploring the dynamics of carbon and nitrogen turnover from two different muscles during the first days of post-settlement in a coral reef fish. As expected, we found some different patterns of variation in isotopic compositions over time between muscles. When artificial granules were provided, the turnover of both isotopes was faster in the epaxial musculature than in the adductor mandibulae. For algal treatment, the carbon turnovers showed opposite trends for each muscle but this difference was probably mitigated by starvation. Finally, a steadystate system in each muscle tissue of A. triostegus was not reached after a diet shift, at the end of the 24-day experiment. Overall, our results reveal that the metabolism of settling reef fish may be subjected to catabolism or anabolism of non-protein precursors, inducing variation in isotopic compositions.

\section{ACKNOWLEDGEMENTS}

L.G., B.F. and G.L. are respectively a research fellow, a postdoctoral researcher and an associate researcher of the Fonds National de la Recherche Scientifique of Belgium (F.R.S-FNRS). We would like to thank Serge Planes, Yannick Chancerelle, Pascal Ung and Benoit Espiau (CRIOBE, Moorea, French Polynesia) for helping to collect the fishes and for providing hospitality and laboratory facilities. This study was supported by grants from ANR (ANR-06-JCJC 001201 ) and the CRISP programme (Coral Reef Initiative in the South Pacific- C2A). This paper is MARE paper number 299.

\section{REFERENCES}

Ankjærø T., Christensen J.T., Grønkjær P. 2012. Tissue-specific turnover rates and trophic enrichment of stable $\mathrm{N}$ and $\mathrm{C}$ isotopes in juvenile Atlantic cod Gadus morhua fed three different diets. Mar. Ecol. Prog. Ser. 461: 197-209. http://dx.doi.org/10.3354/meps09871

Bosley K.L., Witting D.A., Chambers R.C., et al. 2002. Estimating turnover rates of carbon and nitrogen in recently metamorphosed winter flounder Pseudopleuronectes americanus with stable isotopes. Mar. Ecol. Prog. Ser. 236: 233-240. http://dx.doi.org/10.3354/meps236233

Carassou L., Kulbicki M., Nicola T.J.R., et al. 2008. Assessment of fish trophic status and relationships by stable isotope data in the coral reef lagoon of New Caledonia, southwest Pacific. Aquat. Living Resour. 21: 1-12. http://dx.doi.org/10.1051/alr:2008017

Caut S., Angulo E., Courchamp F. 2009. Variation in discrimination factors $\left(\delta^{15} \mathrm{~N}\right.$ and $\left.\delta^{13} \mathrm{C}\right)$ : The effect of diet isotopic values and applications for diet reconstruction. J. Appl. Ecol. 46: 443-453. http://dx.doi.org/10.1111/j.1365-2664.2009.01620.x

Colborne S.F., Robinson B.W. 2013. Effect of nutritional condition on variation in $\delta^{13} \mathrm{C}$ and $\delta^{15} \mathrm{~N}$ stable isotope values in Pumpkinseed sunfish (Lepomis gibbosus) fed different diets. Environ. Biol. Fish. 96: 543-554. http://dx.doi.org/10.1007/s10641-012-0040-3

Doucett R.R., Booth R.K., Power G., et al. 1999. Effects of the spawning migration on the nutritional status of anadromous Atlantic salmon (Salmo salar): Insights from stable-isotope analysis. Can. J. Fish. Aquat. Sci. 56: 2172-2180. http://dx.doi.org/10.1139/f99-147

Enyidi U., Kiljunen M., Jones R.I., et al. 2013. Nutrient assimilation by first-feeding african catfish, Clarias gariepinus, assessed using stable isotope analysis. J. World Aquacult. Soc. 44: 161-172. http://dx.doi.org/10.1111/jwas. 12016

Ferron A., Leggett W.C. 1994. An appraisal of condition measures for marine fish Larvae. Adv. Mar. Biol. 30: 217-303. http://dx doi.oro/10.1016/S0065-2881(08)60064-4

Filbrun J.E., Culver D.A. 2014. Stable isotopes reveal live prey support growth of juvenile channel catfish reared under intensive feeding regimens in ponds. Aquaculture 433: 125-132. http://dx.doi.org/10.1016/j.aquaculture.2014.06.005

Frédérich B., Adriaens D., Vandewalle P. 2008. Ontogenetic shape changes in Pomacentridae (Teleostei, Perciformes) and their relationships with feeding strategies: a geometric morphometric approach. Biol. J. Linn. Soc. 95: 92-105. http://dx.doi.org/10.1111/j.1095-8312.2008.01003.x

Frédérich B., Fabri G., Lepoint G., et al. 2009. Trophic niches of thirteen damselfishes (Pomacentridae) at the Grand Récif of Toliara, Madagascar. Ichthyol. Res. 56: 10-17. http://dx.doi.org/10.1007/s10228-008-0053-2

Frédérich B., Lehanse O., Vandewalle P., et al. 2010. Trophic Niche Width, Shift, and Specialization of Dascyllus aruanus in Toliara Lagoon, Madagascar. Copeia. 2: 218-226. http://dx.doi.org/10.1643/CE-09-031

Frédérich B., Colleye O., Lepoint G., et al. 2012. Mismatch between shape changes and ecological shifts during the post-settlement growth of the surgeonfish, Acanthurus triostegus. Front. Zool. 9: 8 . http://dx.doi.org/10.1186/1742-9994-9-8

Gajdzik L., Vanreusel A., Koedam N., et al. 2014. The mangrove forests as nursery habitats for the ichthyofauna of Mida Creek (Kenya, East Africa). J. Mar. Biol. Assoc. U.K. 94: 865-877. http://dx.doi.org/10.1017/S0025315414000290

Guelinckx J., Maes J., Van Den Driessche P., et al. 2007. Changes in $\delta^{13} \mathrm{C}$ and $\delta^{15} \mathrm{~N}$ in different tissues of juvenile sand goby Pomatoschistus minutus: A laboratory diet-switch experiment. Mar. Ecol. Prog. Ser. 341: 205-215. http://dx.doi.org/10.3354/meps341205 
Hata H., Umezawa Y. 2011. Food habits of the farmer damselfish Stegastes nigricans inferred by stomach content, stable isotope, and fatty acid composition analyses. Ecol. Res. 26: 809-818. http://dx.doi.org/10.1007/s11284-011-0840-5

Hernandez-Lagunas L., Choi I.F., Kaji T., et al. 2005. Zebrafish narrowminded disrupts the transcription factor prdm 1 and is required for neural crest and sensory neuron specification. Dev. Biol. 278: 347-357. http://dx.doi.org/10.1016/j.ydbio.2004.11.014

Herzka S.Z., Holt G.J. 2000. Changes in isotopic composition of red drum (Sciaenops ocellatus) larvae in response to dietary shifts: Potential applications to settlement studies. Can. J. Fish. Aquat. Sci. 57: 137-147. http://dx.doi.org/10.1139/f99-174

Hesslein R.H., Hallard K.A., Ramlal P. 1993. Replacement of sulfur, carbon, and nitrogen in tissue of growing broad whitefish (Coregonus nasus) in response to a change in diet traced by $\delta^{34} \mathrm{~S}, \delta^{13} \mathrm{C}$, and $\delta^{15}$ N. Can. J. Fish. Aquat. Sci. 50: 2071-2076. http://dx.doi.org/10.1139/f93-230

Lauder G.V. 1980. Evolution of the feeding mechanism in primitive actinopterygian fishes: A functional anatomical analysis of Polypterus, Lepisosteus, and Amia. J. Morphol. 163: 283-317. http://dx.doi.org/10.1002/jmor.1051630305

Lecchini D. 2005. Spatial and behavioural patterns of reef habitat settlement by fish larvae. Mar. Ecol. Prog. Ser. 301: 247-252. http://dx.doi.org/10.3354/meps301247

Lecchini D., Galzin R. 2003. Synthèse sur l'influence des processus pélagiques et benthiques, biotiques et abiotiques, stochastiques et déterministes, sur la dynamique de l'autorecrutement des poissons coralliens. Cybium 27: 167-184.

Lecchini D., Galzin R. 2005. Spatial repartition and ontogenetic shifts in habitat use by coral reef fishes (Moorea, French Polynesia). Mar. Biol. 147: 47-58. http://dx.doi.org/10.1007/s00227-004-1543-Z

Lecchini D., Polti S., Nakamura Y., et al, 2006. New perspectives to aquarium fish trade. Fish. Sci. 72: 40-47. http://dx.doi.org/10.1111/j.1444-2906.2006.01114.x

Leis J.M. 2002. Pacific coral-reef fishes: The implications of behaviour and ecology of larvae for biodiversity and conservation, and a reassessment of the open population paradigm. Environ. Biol. Fish. 65: 199-208. http://dx.doi.org/10.1023/A:1020096720543

Lepoint G., Dauby P., Gobert S. 2004. Applications of C and N stable isotopes to ecological and environmental studies in seagrass ecosystems. Mar. Pollut. Bull. 49: 887-891. http://dx.doi.org/10.1016/j.marpolbul.2004.07.005

Logan J.M., Jardine T.D., Miller T.J., et al. 2008. Lipid corrections in carbon and nitrogen stable isotope analyses: Comparison of chemical extraction and modelling methods. J. Anim. Ecol. 77: 838-846.

http://dx.doi.org/10.1111/j.1365-2656.2008.01394.x

Maruyama A., Yamada Y., Rusuwa B., et al. 2001. Change in stable nitrogen isotope ratio in the muscle tissue of a migratory goby, Rhinogobius sp., in a natural setting. Can. J. Fish. Aquat. Sci. 58: $2125-2128$. http://dx.doi.org/10.1139/f01-147

McCormick M.I. 1999. Delayed metamorphosis of a tropical reef fish (Acanthurus triostegus): A field experiment. Mar. Ecol. Prog. Ser. 176: 25-38. http://dx.doi.org/10.3354/meps176025

McCormick M.I., Makey L.J. 1997. Post-settlement transition in coral reef fishes: Overlooked complexity in niche shifts. Mar. Ecol. Prog. Ser. 153: 247-257. http://dx.doi.org/10.3354/meps153247

McCormick M.I., Molony B.W. 1992. Effects of feeding history on the growth characteristics of a reef fish at settlement. Mar. Biol. 114: $165-173$.
Mill A.C., Pinnegar J.K., Polunin N.V.C. 2007. Explaining isotope trophic-step fractionation: why herbivorous fish are different. Funct. Ecol. 21:1137-1145. http://dx.doi.org/10.1111/j.1365-2435.2007.01330.x

Motulsky H.J. 2007. Prism 5 Statistics Guide, GraphPad Software Inc., San Diego CA, www.graphpad.com.

Ogden J.C., Lobel P.S. 1978. The role of herbivorous fishes and urchins in coral reef communities. Environ. Biol. Fish. 3: 49-63. http://dx.doi.org/10.1007/BF00006308

Olsen S.A., Hansen P.K., Givskud H., et al. 2015. Changes in fatty acid composition and stable isotope signature of Atlantic cod (Gadus morhua) in response to laboratory dietary shifts. Aquaculture 435: 277-285 http://dx.doi.org/10.1016/j.aquaculture.2014.09.039

Pinnegar J.K., Polunin N.V.C. 1999. Differential fractionation of $\delta^{13} \mathrm{C}$ and $\delta^{15} \mathrm{~N}$ among fish tissues: implications for the study of trophic interactions. Funct. Ecol. 13: 225-231. http://dx.doi.org/10.1046/j.1365-2435.1999.00301.x

Randall J.E. 1961. A contribution to the biology of the convict surgeonfish of the Hawaiian Islands, Acanthurus triostegus sandoicensis. Pac. Sci. 15: 215-272.

Rowlerson A., Scapolo P.A., Mascarello F., et al. 1985. Comparative study of myosins present in the lateral muscle of some fish: species variations in myosin isoforms and their distribution in red, pink and white muscle. J. Muscle Res. Cell Motil. 6: 601-640. http://dx.doi.org/10.1007/BF00711917

Sampey A., McKinnon A.D., Meekan M.G., et al. 2007. Glimpse into guts: overview of the feeding of larvae of tropical shorefishes. Mar. Ecol. Prog. Ser. 339: 243-257. http://dx.doi.org/10.3354/meps339243

Schmidt K., Atkinson A., Stübing D., et al. 2003. Trophic relationships among Southern Ocean copepods and krill: Some uses and limitations of a stable isotope approach. Limnol. Oceanogr. 48: 277-289. http://dx.doi.org/10.4319/1o.2003.48.1.0277

Sweeting C.J., Polunin N.V.C., Jennings S. 2006. Effects of chemical lipid extraction and arithmetic lipid correction on stable isotope ratios of fish tissues. Rapid Commun. Mass. Sp. 20: 595-601. http://dx.doi.org/10.1002/rcm.2347

Tanaka Y., Minami H., Ishihi Y., et al. 2014. Relationship between prey utilization and growth variation in hatchery-reared Pacific bluefin tuna, Thunnus orientalis (Temminck et Schlegel), larvae estimated using nitrogen stable isotope analysis. Aquacult. Res. 45: 537-545. http://dx.doi.org/10.1111/j.1365-2109.2012.03258.x

Tieszen L.L., Boutton T.W., Tesdahl K.G., et al. 1983. Fractionation and turnover of stable carbon isotopes in animal tissues: Implications for $\delta^{13} \mathrm{C}$ analysis of diet. Oecologia 57: 32-37. http://dx.doi.org/10.1007/BF00379558

Vanderklift M.A., Ponsard S. 2003. Sources of variation in consumer-diet $\delta^{15} \mathrm{~N}$ enrichment: A meta-analysis. Oecologia 136: $169-182$ http://dx.doi.org/10.1007/s00442-003-1270-z

Vandewalle P. 1978. Analyse des mouvements potentiels de la région céphalique du goujoun, Gobio gobio (L.) (Poissons, Cyprinidae). Cybium 3: 15-33.

Wilson R.P. 1994. Utilization of dietary carbohydrate by fish. Aquaculture 124: 67-80. http://dx.doi.org/10.1016/0044-8486(94)90363-8

Wyatt A.S.J., Waite A.M., Humphries S. 2010. Variability in isotope discrimination factors in coral reef fishes: Implications for diet and food web reconstruction. PLoS One 5: e13682. http://dx.doi.org/10.1371/journal.pone.0013682 